All our tests with the Navicula sp. were negative. It was apparent, therefore, that this was not the cause of trouble but that Fragilaria striatula was suspect. This is in agreement with the report of Fraser and Lyell (1963) that an eczematous eruption in an Aberdeen fisherman was caused by Fragilaria stratula. That this diatom, alone out of so many present in the sea, should have a harmful effect when concentrated is at first sight surprising. It is not exceptionally active in producing mucilage, but it does have the characteristic of being weakly silicified. Possibly some excretory or other metabolic product diffuses out from the cells. It must be borne in mind, however, that there are few occasions when large concentrations of diatoms are likely to come in contact with human skin and that there may be numbers of species which might have the effect if present in sufficient quantities.

Incidentally, it may be noted that Dogger Bank itch, a hazard of trawler fishermen, first described by Bonnevie (1948) and subsequently by Newhouse (1966) and Schilling et al. (1966), was found to be due to a marine animal, Alcyonidium hirsutum or Alcyonidium gelatinosum.

Since the summer of 1967 one of the men investigated has purchased an American-manufactured "Hydroslave automatic pot hauler." This device is fitted to the boat and raises the lobster pots mechanically after the marker float has been lifted, by hand, out of the water and attached to the machine. Manual hauling on the ropes is unnecessary. Our first patient has installed a small capstan in his boat to haul up the pots mechanically.

\section{Summary}

Dermatological lesions may be seen in lobster fishermenthese are chiefly the result of physical and chemical trauma and infection. One case of sensitization to the "diatom weed" which collects on the lobster-pot ropes is recorded. It seems likely that the active constituent of this weed is Fragilaria striatula.

We would like to thank Dr. J. Lloyd Lewis for his assistance in this work.

\section{REFERENCES}

Bonnevie, P. (1948). Acta allerg. (Kbh.), 1, 40. Fraser, J. H., and Lyell, A. (1963). Lancet, 1, 61. Gross, F. (1937). 7. mar. biol. Ass. U.K., 21,753. Newhouse, M. L. (1966). Brit. med. ¥., 1, 1142.

Schilling, R. S. F., Newhouse, M. L., Heather, C. H., Turk, J. L. Parker, D., and Rudner, E. J. (1966). Proc. roy. Soc. Med., 59, i119.'

\title{
Metabolic Acidosis in Burns
}

\author{
M. J. T. PEASTON,* M.B., PH.D., M.R.C.P.GLASG.
}

Brit. med. F., 1968, 1, 809-811

Though there is an awareness that metabolic acidosis may complicate burns, there is a remarkable paucity of quantitative information on the subject. A number of authoritative reviews on the early management of burns make no mention of metabolic acidosis as a therapeutic problem (Colebrook, 1951 ; Hay and Cronin, 1954 ; Wilkinson, 1957 ; Bocanegra et al., 1966 ; Barclay, 1967 ; Lancet, 1967), even though alkali therapy is often advocated. Acidosis is not mentioned among the causes of mortality from burns in reviews which quote up to 24 predisposing factors (Rush, 1953 ; Winterscheid and Merendino, 1960 ; Phillips and Cope, 1962 ; Hockmuth and Ziffren, 1963 ; Birke et al., 1964 ; Feller and Hendrix, 1964). There is no literature presenting acid-base studies obtained with reliable modern electrodes for measuring arterial $\mathrm{pH}$ and $\mathrm{PCO}_{2}$.

The present study was undertaken in a regional burns unit to investigate the acid-base status of patients during the early post-burn period, and to study the relation between severity of acid-base disturbance and extent of the burn.

\section{Patients}

Fourteen consecutive unselected patients admitted to a regional burns unit with burns of more than $15 \%$ of the total body surface area were studied. Their ages ranged from 17 to 71 years, and the group includes seven male and seven female subjects (Table I). The severity of burn was assessed in terms of total extent and of partial and full skin thickness involvement. The distinction between partial and full skin thickness was made on clinical grounds, and the percentage of each degree of burn related to the total surface area calculated from standard tables relating surface area to height and body weight. Total extent of burn varied from 18 to $70 \%$ of the surface - Clinical Pharmacology and Intensive Care Units, Whiston Hospital,
Prescot, Lancs. area, with ranges of 4 to $55 \%$ for partial skin thickness and of 3 to $45 \%$ for full skin thickness involvement.

\begin{tabular}{|c|c|c|c|c|c|c|}
\hline \multirow[b]{2}{*}{$\begin{array}{l}\text { Case } \\
\text { No. }\end{array}$} & \multirow[b]{2}{*}{ Age } & \multirow[b]{2}{*}{ Sex } & \multicolumn{3}{|c|}{ Percentage of Surface Area Burned } & \multirow[b]{2}{*}{ Outcome } \\
\hline & & & Total & $\begin{array}{c}\text { Partial } \\
\text { Skin } \\
\text { Thickness }\end{array}$ & 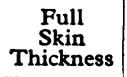 & \\
\hline $\begin{array}{r}1 \\
2 \\
3 \\
4 \\
5 \\
6 \\
7 \\
8 \\
9 \\
10 \\
11 \\
12 \\
13 \\
14\end{array}$ & $\begin{array}{l}28 \\
19 \\
39 \\
48 \\
36 \\
17 \\
71 \\
35 \\
46 \\
18 \\
39 \\
40 \\
34 \\
67\end{array}$ & $\begin{array}{l}M \\
M \\
F \\
F \\
F \\
M \\
F \\
M \\
F \\
M \\
F \\
M \\
M \\
F\end{array}$ & $\begin{array}{l}30 \\
65 \\
18 \\
50 \\
40 \\
36 \\
40 \\
20 \\
35 \\
20 \\
20 \\
70 \\
33 \\
40\end{array}$ & $\begin{array}{r}5 \\
55 \\
9 \\
5 \\
4 \\
7 \\
4 \\
12 \\
27 \\
17 \\
5 \\
35 \\
28 \\
20\end{array}$ & $\begin{array}{r}25 \\
10 \\
9 \\
45 \\
36 \\
29 \\
36 \\
8 \\
8 \\
3 \\
15 \\
35 \\
5 \\
20\end{array}$ & $\begin{array}{l}\text { Lived } \\
\text { ” } \\
\text { Died } \\
\text { Lived } \\
\text { Died } \\
\text { Lived } \\
\text { ” } \\
\text { D"̈ } \\
\text { Lived } \\
\text { ” }\end{array}$ \\
\hline
\end{tabular}

Four of the patients died, all with $35 \%$ or more of full skin thickness burns. Similarly all the patients with more than $40 \%$ of total surface area burned failed to survive except for one patient (Case 2) in whom the large surface area involved was predominantly by partial skin thickness burn.

\section{Methods}

Acid-base measurements were made on arterial blood samples obtained by intermittent femoral puncture. Arterial $\mathrm{pH}$ was measured on an Astrup $\mathrm{pH}$ electrode (Radiometer, Copenhagen), and arterial $\mathrm{PCO}_{2}$ on a Severinghaus $\mathrm{PcO}_{2}$ electrode (Severinghaus and Bradley, 1958). The severity of acidosis was expressed in terms of the base deficit (Siggaard Andersen et al., 1960), obtained by interpolation from the Siggaard Andersen (1962) 
nomogram. The quantity of sodium bicarbonate required for correction of acidosis was calculated from the equation:

$\mathrm{mEq}$ of bicarbonate required $=0.3 \times$ base deficit $\times$ body weight $(\mathrm{kg}$.) (Mellengaard and Astrup, 1960).

Significant respiratory alkalosis was assumed when arterial $\mathrm{PCO}_{2}$ was below $30 \mathrm{~mm}$. $\mathrm{Hg}$ (normal $33-43 \mathrm{~mm}$. Hg). Uncompensated acidosis was adjudged present when arterial $p \mathrm{H}$ fell below 7.35 (normal 7.38-7.45). Sodium bicarbonate was administered as an $8.4 \%$ solution ( $1 \mathrm{mEq}$ of bicarbonate per ml.) intravenously. The frequency of acid-base measurements depended on the severity of the acid-base changes observed, and the number of estimations per patient varied from 3 to 19 , with a mean for all patients of 8.4. Measurements were made daily, or more frequently if the acid-base problem was particularly serious. Estimations were discontinued when the acidbase problem had either been corrected or was not serious enough to warrant further arterial sampling. In 8 of the 14 patients routine external balance studies were carried out for water, sodium, potassium, chloride, and total nitrogen during nasogastric or intravenous feeding by methods described elsewhere (Peaston, 1966a, 1966b).

\section{Results}

Twelve of the 14 patients had a base deficit at some stage after thermal injury, and in seven of these the metabolic acidosis was maximal on admission and in three others within 24 hours (Table II). In four cases with a base deficit of less than -4 no sodium bicarbonate was administered. With more serious degrees of acidosis the bicarbonate requirement was variable, as is well exemplified by two patients (Cases 2 and 12) in whom acidosis of comparable severity was in one instance corrected by $400 \mathrm{mEq}$ given over 24 hours, while in the other $2,750 \mathrm{mEq}$ was required over a period of 11 days.

Table II.-Degree of Maximum Metabolic Acidosis in 14 Patients

\begin{tabular}{|c|c|c|c|c|c|c|c|}
\hline $\begin{array}{l}\text { Case } \\
\text { No. }\end{array}$ & $\begin{array}{c}\text { Total } \\
\text { Area } \\
\text { Burned } \\
(\%)\end{array}$ & $\begin{array}{c}\text { Maximum } \\
\text { Base } \\
\text { Deficit } \\
\text { (mEq) }\end{array}$ & $\begin{array}{c}\text { Time of } \\
\text { Maximum } \\
\text { Base Deficit }\end{array}$ & $\begin{array}{c}\text { Lowest } \\
p \mathrm{H}\end{array}$ & $\begin{array}{l}\text { Lowest } \\
\mathrm{PCO}_{3}\end{array}$ & $\begin{array}{c}\text { Total } \\
\mathrm{NaHCO}_{3} \\
\text { Given } \\
\text { (mEq) } \\
\end{array}$ & $\begin{array}{c}\text { Time Over } \\
\text { which } \\
\mathrm{NaHCO}_{3} \\
\text { Given }\end{array}$ \\
\hline $\begin{array}{r}1 \\
2 \\
3 \\
4 \\
5 \\
6 \\
7 \\
8 \\
9 \\
10 \\
11 \\
12 \\
13 \\
14\end{array}$ & $\begin{array}{l}30 \\
65 \\
18 \\
50 \\
40 \\
36 \\
40 \\
20 \\
35 \\
20 \\
20 \\
70 \\
33 \\
40\end{array}$ & $\begin{array}{l}-2 \\
=15 \\
=4 \\
=6 \\
-10 \\
=31 \\
=8 \frac{1}{2} \\
+2 \\
=3 \\
=1 \frac{1}{3} \\
-17 \\
=7 \\
=6\end{array}$ & $\begin{array}{l}\text { On admission } \\
7 \text { days } \\
\text { On admission } \\
24 \text { hours } \\
\text { On admission } \\
24 \text { hour" } \\
4 \text { days } \\
\text { On admission } \\
\text { On admission } \\
24 \text { hours" }\end{array}$ & $\begin{array}{l}7 \cdot 48 \\
7 \cdot 40 \\
7 \cdot 41 \\
7 \cdot 48 \\
7 \cdot 42 \\
7 \cdot 45 \\
7 \cdot 42 \\
7 \cdot 52 \\
7 \cdot 43 \\
7 \cdot 48 \\
7 \cdot 42 \\
7 \cdot 30 \\
7 \cdot 40 \\
7 \cdot 52\end{array}$ & $\begin{array}{l}26 \\
14 \\
30 \\
20 \\
19 \frac{1}{1} \\
26 \frac{1}{2} \\
22 \\
27 \\
29 \\
26 \\
35 \\
16 \\
26 \\
20\end{array}$ & $\begin{array}{l}2, \overline{750} \\
\overline{150} \\
\overline{900} \\
\overline{500} \\
\overline{50} \\
\overline{-} \\
400 \\
150 \\
200\end{array}$ & $\begin{array}{l}11 \text { days } \\
4 \text { days } \\
7 \text { "” } \\
2 \text { days } \\
4 \text { days } \\
24 \text { hours } \\
24 \text { "y }\end{array}$ \\
\hline $\begin{array}{l}\text { Total } \\
\text { Mean }\end{array}$ & & & & & & $\begin{array}{l}5,100 \\
164 / \text { day }\end{array}$ & $\begin{array}{l}31 \text { days } \\
3.9 ״\end{array}$ \\
\hline
\end{tabular}

The relation between acidosis and extent and depth of the burn was investigated by plotting the maximum base deficit in each patient against burned surface area. There was no close relation between maximum acidosis and either partial skin thickness or full skin thickness burn (Table II). When, however, maximum base deficit was related to the total surface area burned there was a definite relation between the two (see Chart). The more extensive the burn the greater the degree of maximum base deficit in each patient. Above $30 \%$ of total surface area this relation was linear.
The results of external balance studies on the eight patients to whom they were applied are summarized in Table III. These showed a mean sodium retention of $48 \mathrm{mEq} /$ day and chloride retention of $21 \mathrm{mEq} /$ day. These results do not indicate an increase of total body chloride relative to sodium.

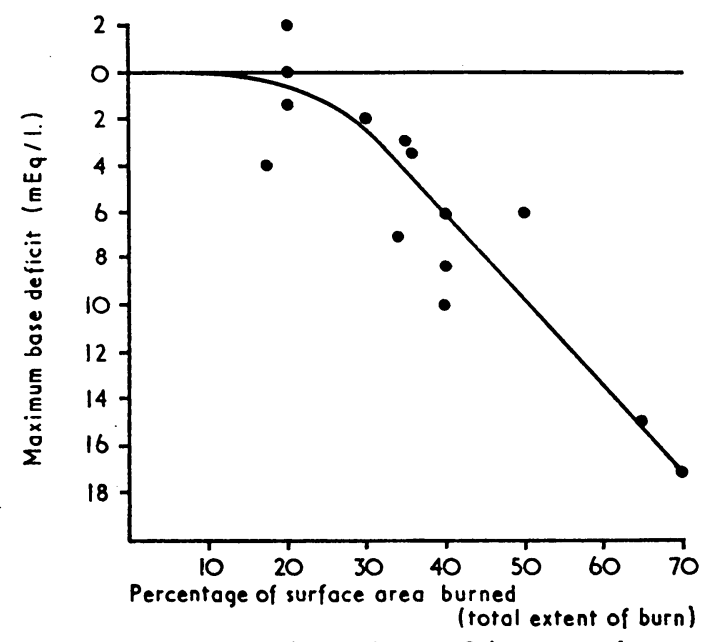

Relation between maximum base deficit and total extent of burn.

\section{Discussion}

Fox (1944) found that sodium bicarbonate given after burns improved urine output and prevented albuminuria and azotaemia. Harkins et al. (1945) wrote: "If the severely burned patient has received no fluid therapy for several hours after the time of injury, acidosis is not infrequent; this is particularly likely ... in shock. . . . Acidosis should be promptly treated." He attributed the acidosis to dehydration and shock, and suggested $1.3 \%$ sodium bicarbonate for its treatment. Sodium bicarbonate was also suggested by Moyer et al. (1944) after an experimental study in dogs. Reiss et al. (1953) suggested that Ringer-lactate solution might " offset the tendency towards acidosis that is frequently seen in the early postburn period." The cause of the acidosis has variously been ascribed to acute sodium depletion or to exaggeration of hyperchloraemia from the liberal use of normal saline (Kaye, 1956; Clark, 1961). However, Fox et al. (1955) studied 12 patients with burns and found that hyperchloraemic acidosis was a common finding on admission, though his acid-base measurements were confined to the alkali reserve, and $p \mathrm{H}$ was calculated from the Henderson-Hasselbalch equation. Others have also pointed out that the acidosis presents early (Artz and Hoopes, 1962).

The limited study reported here shows clearly that acidosis following thermal injury is common, and is most pronounced on admission. The acidosis is usually compensated by respiratory alkalosis. Though there is no close correlation between the maximum base deficit in each patient and the extent of partial or full skin thickness burn, there is a definite relation between the severity of acidosis and the total body surface area burned. When the total extent of burn exceeded $30 \%$ of the surface area acidosis became a progressively more serious problem the greater the extent of burn. The acidosis observed could not be ascribed to saline therapy exacerbating pre-existing

TABle III.-External Balance Data on Eight Burned Patients

\begin{tabular}{|c|c|c|c|c|c|c|c|c|c|c|c|c|c|c|c|c|c|c|c|c|c|c|}
\hline \multirow{3}{*}{$\begin{array}{l}\text { No. of } \\
\text { Cases }\end{array}$} & \multirow{3}{*}{$\begin{array}{c}\text { Dura- } \\
\text { tion of } \\
\text { Balance } \\
\text { (days) } \\
\end{array}$} & \multicolumn{6}{|c|}{ Mean Intake } & \multicolumn{5}{|c|}{ Mean Output } & \multicolumn{4}{|c|}{ Mean Uncorrected Balance } & \multicolumn{5}{|c|}{ Mean Corrected Balance } & \multirow{4}{*}{$\begin{array}{c}\text { Loss of } \\
\text { Lean } \\
\text { Muscle } \\
\text { Mass } \\
\text { (g./day) }\end{array}$} \\
\hline & & \multirow{2}{*}{ Cal. } & \multirow{2}{*}{$\begin{array}{c}\mathrm{H}_{2} \mathrm{O} \\
(1 .) \\
\end{array}$} & $\mathrm{Na}$ & $\mid \mathbf{K}$ & $\mathrm{Cl}$ & \multirow{2}{*}{$\begin{array}{l}\mathrm{N}_{\mathbf{2}} \\
\text { (g.) }\end{array}$} & \multirow{2}{*}{$\begin{array}{c}\mathrm{H}_{2} \mathrm{O} \\
(1 .) \\
\end{array}$} & $\mathrm{Na} \mid$ & $\mathrm{K} \mid \mathrm{C}$ & $\mathrm{Cl}$ & \multirow{2}{*}{$\begin{array}{l}\mathrm{N}_{\mathbf{2}} \\
\text { (g.) } \\
\end{array}$} & \multirow{2}{*}{$\begin{array}{c}\mathrm{H}_{2} \mathrm{O} \\
\text { (1.) }\end{array}$} & $\mathbf{N a}$ & $\mathbf{K} \mid \mathbf{C l}$ & \multirow{2}{*}{$\begin{array}{l}\mathbf{N}_{2} \\
\text { (g.) }\end{array}$} & \multirow{2}{*}{$\begin{array}{c}\mathrm{H}_{2} \mathrm{O} \\
\text { (1.) } \\
\end{array}$} & $\mathrm{Na} \mid$ & $\mathbf{K}$ & $\mathbf{C l}$ & \multirow{2}{*}{$\begin{array}{l}\mathbf{N}_{\mathbf{z}} \\
(\mathbf{g} .)\end{array}$} & \\
\hline & & & & & $\mathrm{mEq}$ & & & & & $\mathrm{nEq}$ & & & & & $\mathrm{mEq}$ & & & & $\mathrm{mEq}$ & & & \\
\hline 8 & 5.6 & 4,132 & $6 \cdot 15$ & 363 & $|139|$ & 315 & $19 \cdot 2$ & 3.97 & 190 & $97 \mid 18$ & 188 & $21 \cdot 03$ & $2 \cdot 18$ & 173 & $42|127|$ & -1.83 & 0.18 & 48 & -39 & 21 & $-4 \cdot 23$ & \\
\hline
\end{tabular}


hyperchloraemia. Though the mean balance data on eight of the patients show chloride retention, this is less than the retention of sodium or loss of potassium. The observations on electrolyte and nitrogen balance reflect the metabolic response to thermal injury rather than change in the acid-base state.

The therapeutic implications of this study are clear. In acute severe illnesses metabolic acidosis commonly predisposes to acute renal failure (Peaston, 1967). Renal failure in severe burns is by no means uncommon; in some series it is quoted as the fourth most common cause of death, responsible for $9 \%$ of all fatalities (Phillips and Cope, 1962), while in other series it is said to be the second commonest fatal complication (Hockmuth and Ziffren, 1963). With better methods of fluid replacement and treatment of shock, and with improved techniques of surgical care and prevention of secondary infection in the burn itself, the proper management of acid-base disturbances assumes a role of even greater importance. I agree with Artz (1960) that in burns "acute renal failure does not occur unless there is gross neglect in treatment." It is suggested that the quantitative evaluation of metabolic acidosis and its early correction with sodium bicarbonate is an important measure in preventing renal failure in burns, and is more likely to preserve a healthy milieu intérieur during the critical early period after thermal injury. In view of the small number of patients with extensive burns studied in this series it is suggested that further observations be made in severe burns to confirm the findings reported.

\section{Summary}

The acid-base state has been studied by means of serial arterial $\mathrm{pH}$ and $\mathrm{PCO}_{2}$ measurements in 14 patients admitted to a regional burns unit. Metabolic acidosis was a common finding, and in the majority of patients was maximal on or shortly after admission. The maximum degree of acidosis in each patient expressed in terms of the base deficit was found to correlate closely with the total extent of body surface area burned, though there was no close relation between maximum acidosis and either partial or full skin thickness involvement. The severe degrees of base deficit observed were usually com- pensated by respiratory alkalosis. Above $30 \%$ of surface area burned the severity of acidosis increased linearly with the extent of the burn. The therapeutic implications are discussed.

I should like to thank Mr. D. Maesels and Mr. A. H. M. Littlewood for their kind permission to study their patients admitted to the Regional Burns Unit at Whiston Hospital and for their constant interest and assistance.

\section{REFERENCES}

Artz, C. P. (1960). In Complications in Surgery and Their Management, edited by C.P. Artz and J. D. Hardy. Philadelphia.

Artz, C. P., and Hoopes, J. E. (1962). Amer. F. Surg, 103, 316.

Barclay, T. L. (1967). Hosp. Med., i, 1138.

Birke, G., Lilijedahl, S.-O., Bäckdahl, M., and Nylén, B. (1964). Acta chir. scand., Suppl. No. 337.

Bocanegra, M., Hinostroza, F., Kefalides, N. A., Markley, K., and

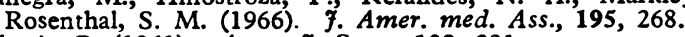

Clark, A. G. (1961). Amer. F. Surg., 102, 231.

Colebrook, L. (1951). Lancet, 2, 273.

Feller, I., and Hendrix, R. C. (1964). Surg. Gynec. Obstet., 119, 1.

Fox, C. L. (1944). F. Amer. med. Ass., 124, 207.

Fox, C. L., Lasker, S. E., Winfield, J. M., Mersheimer, W. L., and Silverstein, M. E. (1955). Amer. F. Surg., 98, 730.

Harkins, H. N., Cope, O., Evans, E. I., Phillips, R. A., and Richards, D. W. (1945). F. Amer. med. Ass., 128, 475 .

Hay, E. B., and Cronin, T. D. (1954)., Amer. F. Surg., 87, 84.

Hockmuth R. E., and Ziffren, S. E. (1963). Surg. Gynec. Obstet., 117, 540 .

Kaye, B. B. (1956). Amer. 7. Surg., 92, 123.

Lancet, 1967, 2, 814 .

Mellemgaard, K., and Astrup, P. (1960). Scand. F. clin. Lab. Invest., 12, 187 .

Moyer, C. A., Coller, F. A., Iob, V., and Vaughan, H. H. (1944). Ann. Surg. 120, 367.

Peaston, M. J. T. (1966a). Brit. med. 7., 2, 1367.

Peaston, M. J. T. (1966b). Brit. med. Ұ., $2,388$.

Peaston, M. J. T. (1967). Postgrad. med. Э., 43, 317.

Phillips, A. W., and Cope, O. (1962). In Research in Burns : Proceedings of the first international congress, edited by $C$. P. Artz. Washington. Reiss, E., Stirman, J. A., Artz, C. P., Davis, J. H., and Amspacher, W. H. (1953). \%. Amer. med. Ass., 152, 1309

Rush, J. T. (1953). Amer. F. Surg., 85, 187.

Severinghaus, J. W., and Bradley, A. F. (1958). F. appl. Physiol., 13, 515 Siggaard Andersen, O. (1962). Scand. $\}$. clin. Lab. Invest., 14, 598. Siggaard Andersen, O., Engel, K., Jorgensen, K., and Astrup, P. (1960). Scand. F. clin. Lab.: Invest., 12, 172 .

Wilkinson, A. W. (1957). Brit.' Y. plast. Surg., 10, 275.

Winterscheid, L. C., and Merendino, K. A. (1960). Amer. F. Surg., 100, 375.

\section{Medical Memoranda}

\section{Meckel through Winslow-? Littré}

Brit. med. F., 1968, 1, $811-812$

Intestinal obstruction with herniation through the foranien of Winslow is a relatively uncommon surgical emergency, though it is usually seen once or more in the experience of most surgeons (Silverstone, 1939).

In a comprehensive review of the literature Erskine (1967) states, "Ninety patients have been reported up to 1966 . Although the actual incidence is probably higher than this figure would indicate, the obvious rarity of the condition, its subtle diagnostic features, and the high mortality rate have usually motivated the surgeons, radiologists, and pathologists involved with these patients to report them. This is suggested by the fact that these reports have not referred to additional unreported patients with whom the author was familiar."

Inflammation or incarceration of a Meckel's (1809) diverticulum in a hernial sac, sometimes called a Littré's (1719) hernia, is an emergency of similar rarity (Meyerowitz, 1958). The combination of both these disorders is extremely uncommon, and has only once before been recorded (Cullen, 1954). That this case was unique was confirmed in Erskine's review (1967).

\section{CASE REPORT}

A 46-year-old man was first seen 12 hours after the onset of severe colicky abdominal pain. Before this attack he had suffered only mild intermittent dyspepsia, for which he had taken alkalis with relief. The pain was maximal at its onset, which occurred while he was eating breakfast. Though poorly localized, the pain was severe and the patient was given an injection of $100 \mathrm{mg}$. of pethidine by his general practitioner. As the effect of the pethidine wore off the pain returned and he had a small food vomit. The provisional diagnosis of biliary colic having been made, he was given a further $100 \mathrm{mg}$. of pethidine, but as the effect of this wore off the pain persisted and he was admitted to hospital. On admission he had a dry tongue and was thirsty. The pulse was 96, temperature $98.4^{\circ}$ F. $\left(36.9^{\circ}\right.$ C.), B.P. $160 / 100$, and $\mathrm{Hb} 97 \%$. Abdominal examination revealed no distension but an area of tenderness localized to the right subcostal margin over the gall bladder and the duodenum. Deep inspiration did not aggravate the pain or tenderness. There were no other abnormal physical signs. A supine film of the abdomen showed gaseous distension of the stomach with a 